\title{
Rethinking Teacher Education Programmes for Inclusive Classrooms: Issues and Challenges in India
}

\author{
Pushpa Kumari, Rajiv Nayan, S. P Aggarwal, and Geetanjali Baswani
}

\begin{abstract}
Inclusive education has been internationally recognized as a philosophy for attaining equity, justice and quality education for all children, especially those who have been traditionally excluded from mainstream education for reasons of disability, ethnicity, gender or other characteristics. Inclusion of children with special needs in mainstream education demands the preparation of teachers to suit their needs. The need for teachers who have both the knowledge and the ability to teach in an inclusive classroom is more critical today than ever before. There are lots of challenges in India combined with socially and economically complicated contexts.

This paper identifies key concepts associated with inclusive education and discusses them in relation to issues and challenges in the reform of teacher education. It argues that the reform of teacher education for inclusive education is an important activity in improving educational equity and addressing diversity in education. It also highlights the important role teacher plays to bridge the gap between inclusive policies and practices in India.
\end{abstract}

Index Terms-Inclusive education, children with special needs, equality, empowerment, diversity.

\section{INTRODUCTION}

Since the mid-1990s, the philosophy of inclusion has been influential in changing the provision of education to students with disabilities and learning difficulties. Inclusion requires the provision of an education system that can meet the needs of all learners in local schools. It is, in essence, a philosophical move away from the accommodation of students with special needs into an already existing system, towards a model where all individuals have the right to an education that meets their needs. Inclusion is situated within a broad social justice agenda supported by United Nations policies that affirm the rights of children (for example, the United Nations Convention on the rights of the Child, 1989; the United Nations Standard Rules for the Equalization of Opportunities for Persons with Disabilities 1993; the UNESCO Salamanca Statement, 1994 [1]).

Ref. [2] suggest that it is useful to distinguish between 'narrow' and 'broad' definitions of inclusion. Using their framework, narrow definitions of inclusion refer to the promotion of inclusion for a specific group of students, mainly, students who have disabilities and learning

Manuscript received January 30, 2018; revised August 12, 2018

Pushpa, Kumari and Geetanjali Baswani are with School of Educational studies, Dr. Harisingh Gour Vishwavidyalya, Sagar, Madhya Pradesh, India (e-mail: pushpa.nayan@gmail.com,daisiesgeeta@gmail.com).

Rajiv Nayan is with the Department of Commerce, Ramanujan College, University of Delhi, India (e-mail: rajivnayan32@gmail.com).

S. P Aggarwal is with Principal, Ramanujan College, University of Delhi, India (e-mail: spa15_dbce@yahoo.com). difficulties in 'regular' education settings. On other hand, broad definitions of inclusion focus not on specific groups of students but rather on diversity itself and how schools respond to this diverse needs of all students.

Focusing on individual student learning needs is important in implementing inclusion. Inclusive education requires removing all possible barriers to learning for all. It is vital to remember that responding to individual student needs may require extra learning support or may mean extending and enriching some individuals' school experiences.

\section{A. Understanding Inclusive Teaching Practices}

Inclusive teaching recognizes the classroom reality of diversity by providing multiple ways for students to access content. According to Rouse and Florian 'inclusive pedagogy" is "an approach to teaching and learning that represents a shift in thinking about teaching and learning from that which works for most learners along with something 'different or additional' for those who experience difficulties, to an approach to teaching and learning that involves the creation of a rich learning environment characterized by lessons and learning opportunities that are sufficiently made available to everyone so that all are able to participate in classroom activities." [3]

Schaeffer suggested that a rights-based framework for inclusive pedagogy is necessary to achieve a truly inclusive system of education. This approach advocates interrelated dimensions that work together to ensure that the right to education is granted to everyone without discrimination; learners' rights are respected within their learning environments and access assured through appropriate curricula, materials, and methodologies; and democratic values and respect for human rights are promoted [4].

Importance of Teaching concept of Inclusive Education in Teachers Training Programme:

21 st century education systems have a clear need for teachers who are sufficiently competent and motivated to know how to include children with disabilities and those from other marginalised groups in all classrooms [5]. In order to develop the skills, experience and confidence to be in an inclusive classroom, teachers need to learn about and practice inclusive education during initial teacher preparation. They also need to be given opportunities for continuing in-service professional learning throughout their careers.

The first step in preparing teachers to meet the demands of the inclusive classroom is to define the term, 'inclusive education'. This term is used extensively throughout educational literature, often in differing ways. The UNESCO Policy Guidelines on Inclusion in Education (2009) state that an inclusive education system can only be created if ordinary schools become more open and accepting; in other words, if 
schools become better at educating all the children who live in their communities [6]. For some, inclusive education is solely about ensuring that students with disabilities have the same educational opportunities as their peers. However, in much recent literature, 'inclusion' takes on a broader meaning, which suggests that barriers to inclusive education must be considered at any point in time when the participation of students is restricted. Issues may arise for students as a result of a wide variety of reasons including disability, gender, behaviour, poverty, culture and refugee status [7].

The OECD Report 'Teachers Matter' recognizes that the demands on schools and teachers are becoming more complex as society now expects schools to deal effectively with different languages and student backgrounds, to be sensitive to culture and gender issues, to promote tolerance and social cohesion, to respond effectively to disadvantaged students and students with learning or behavioural problems, to use new technologies, and to keep pace with rapidly developing fields of knowledge and approaches to student assessment. Also, Florian and Rouse state: 'the task of initial teacher education is to prepare people to enter a profession which accepts individual and collective responsibility for improving the learning and participation of all children' [8]. Cardona notes that concentration on initial teacher education '... would seem to provide the best means to create a new generation of teachers who will ensure the successful implementation of inclusive policies and practices' [9]. Taking all this in consideration teachers must be aware of the fact that "education and training systems can increase their capacity to include all learners and to achieve equitable outcomes for all, while meeting the increasing diversity of learners' needs, maintaining cultural diversity and improving quality" [10].

\section{B. Pre-service Preparation of Teachers for Inclusive Education: International Perspective}

In terms of what teachers need to know and be able to do, Florian suggested that educational administrators and decision makers should move beyond debating whether beginning teachers need to know how to improve teaching and learning, or whether they need more specialist knowledge about disability and the learning needs of specific groups of students. She argues that the adults who work in schools need to be better at sharing their professional knowledge and skills with each other. Florian calls for the development and research of new forms of professional knowledge that target inclusive education and which outline ways of working with and through others. It is her belief that the skills and knowledge required for working with adults, and children, should form an essential element of all teacher preparation courses [11]. Ashan, Deppler and Sharma noted that the aim of Institute of teacher education should be to equip teachers who are willing to teach in inclusive classrooms. Overall, they concluded that simply attending inclusive pre-service teacher preparation courses is not sufficient for developing positive values and beliefs. Curriculum content, practicum opportunities and experience with children with disabilities were all deemed to contribute to the better preparation of teacher candidates for inclusive classrooms [12].

\section{Pre-service Preparation of Teachers for Inclusive Education: Indian Perspectives}

Preparation of quality teachers is in great demand over the years and to do so we need to properly design our teacher training programmes. Practice teaching is one of the most important practical activities in pre-service teacher education.

Sandip Kumar and Gopal Rana emphasizes that the inclusive education system requires a more knowledgeable, highly skilled teacher. The most effective way to improve the quality and effectiveness of education programme for inclusive setting is to reach pre-service teachers and teacher educators. There is need for strengthening knowledge, competencies, skills and attitudes of teachers for creating inclusive learning environment in the natural setting. So Pre-service teacher education should provide the knowledge to teachers about the foundational competencies, skill competencies and reflective competencies to meet the unmet challenges of inclusion [13].

The Curriculum Framework for Quality Teacher Education, (National Council for Teacher Education, NCTE, 1998) observed that the practice teaching is now not merely confined to the teaching of certain subjects. Pedagogical analysis of the subjects offered for practice teaching has been made compulsory. The prospective teacher will analyze the subject before going to class and evolve a need-based pedagogy and transactional strategy. The teacher educators will now deliver model lessons of different types in actual classroom situation and the prospective teachers will not only learn the techniques but make its critical appraisal and evaluation to be subsequently discussed with the teachers. Teacher educators supervising the classroom performance, pupil teachers will discuss their observations with them for providing proper feedback to improve their performance. The practice teaching will, thus, require thorough preparation, detailed supervision and adequate time. Its gain would be acquisition of higher level of teaching competencies.

The National Curriculum Framework for Teacher Education (NCTE, 2009) observed that it is common knowledge that practice teaching which constitutes the most functional part of the teacher preparation has suffered severe neglect and dilution in quality. The common complaint is that theory dominates the curriculum and practice teaching continues to suffer from inadequacies of different kinds [14].

Vision of Teacher Education in India Quality and Regulatory Perspective, Report of the High-Powered Commission on Teacher Education Constituted by the Hon'ble Supreme Court of India, Justice Verma Commission (Ministry of Human Resource Development, MHRD, 2012, Volume 1) observed that School experience, based on the model of 'practice teaching' provides piece-meal experiences of functioning as a teacher, mainly because teaching is 'practiced' as a mechanical 'delivery' of a given number of lessons, rather than reflective practice [15].

The above discussion suggests that there is a need to critically review pre-service teacher education practice teaching programme.

\section{OBJECTIVES OF THE STUDY}


This paper identifies key concepts associated with inclusive education and discusses them in relation to issues and challenges in the reform of teacher education. It argues that the reform of teacher education for inclusive education is an important activity in improving educational equity and addressing diversity in education. It also highlights the important role teacher plays to bridge the gap between inclusive policies and practices in India.

\section{MethodOLOGY}

Firstly reviews related to the teacher education curriculum from the perspective of learners with special educational needs and the existing two year B.Ed. curriculum framework of some Universities of India (Jammu and Kashmir, Punjab, Haryana, Uttar Pradesh, Madhya Pradesh, Andhra Pradesh, Delhi, Mumbai, Tamilnadu, Gujarat and Kolkata) were studied and compared.

For critical reviewing the curriculum of Inclusive Education in B.Ed. 2 year Programme, different components i.e. title of the paper and whether its compulsory or elective, year/semester in which the subject is taught, marks allotted to the subject and practical/activities related to the subject were studied and presented in Table I.

TABLE I: CURRICULUM OF DifFERENT UNIVERSITIES IN INCLUSIVE EDUCATION WITH RESPECT to TITLE OF THE PAPER, YEAR/SEMESTER, MARKS AlLOTTED AND PRACTICAL WORK

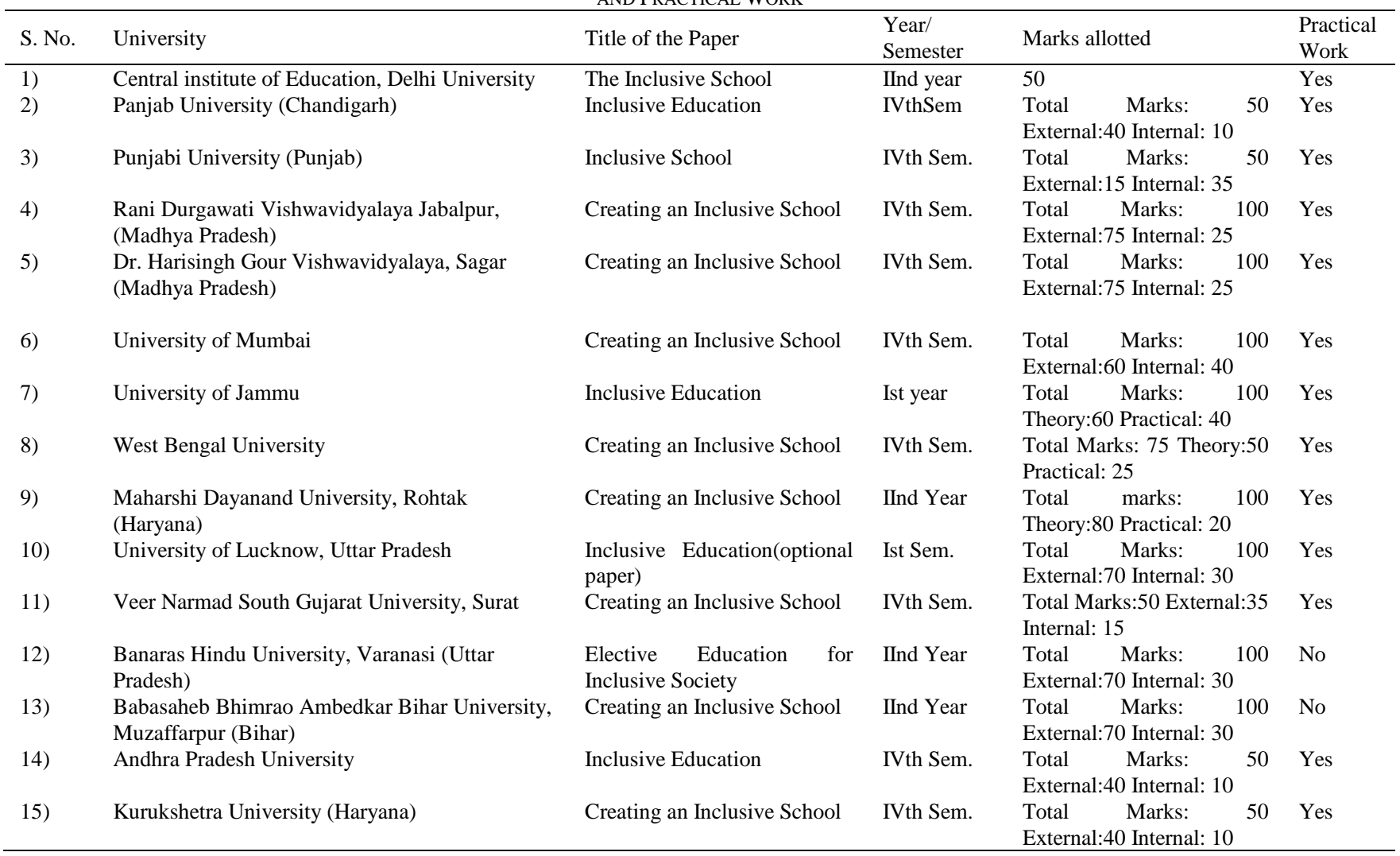

A quantitative survey to identify if pre-service teachers are prepared to face a new reality that of inclusion of all children into the mainstream schools was done. For identifying the issues and challenges faced by teachers in an inclusive classroom and the need to reform teacher education was studied using data collected from questionnaire of $100 \mathrm{~B}$. Ed students of Delhi University undergoing practice teaching in various private, public and government schools. The data provided by this research was analyzed by frequency analysis using SPSS.

We took into consideration 5 quantitative items in the questionnaire, whose aims were to investigate to what extent pre-service teachers feel the need to take training courses in inclusion in order to be prepared to face children with special needs into the classroom. The integration of children with special educational needs has appeared as a necessary reaction to provide high quality education for all children regardless of their mental health issues, emotional and behavioural disorders, race, sex, creed, ethnicity or disability. The first question is entitled to show if children with special needs are included in mainstream schools.

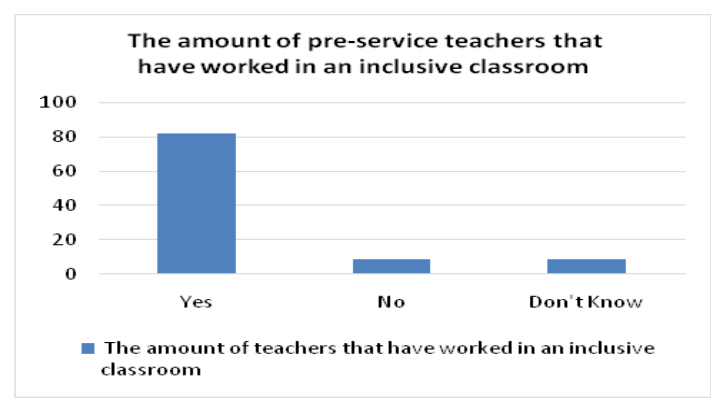

Fig. 1. The amount of pre-service teachers that have worked in an inclusive classroom.

As shown in Fig. 1 approximately $82 \%$ of the questioned 
teachers reported that they have encountered children with special needs in the classes they have worked, which suggest that teachers have to be prepared to respond to those children needs and to respond to diversity in the classroom. A percentage of $9 \%$ of teachers said that they have never worked with children with special needs, meanwhile $9 \%$ of teachers admit that they do not know if they have worked in an inclusive school environment.

The second statistical table Fig. 2 represents the views on barrier free school environment and required resources available in schools for inclusion. $35 \%$ of teachers feel that the school environment and the available resources are good, $42 \%$ feels they have average resources and an average barrier free environment while $23 \%$ feel it poor.

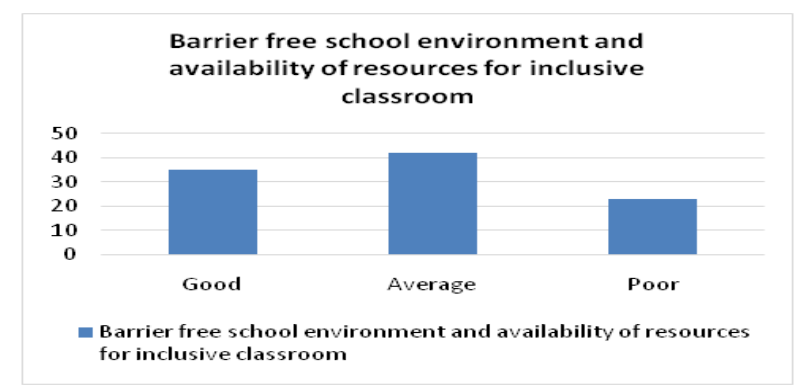

Fig. 2. Barrier free school environment and availability of resources for inclusive classroom.

The statistic presented below Fig. 3 is designed to evaluate the way teachers feel prepared to work in an inclusive classroom. The results show a great majority of teachers declare themselves slightly prepared to teach children with special needs. A vast majority of about $52 \%$ of teachers say that they feel moderately ready whereas $23 \%$ of them consider themselves slightly ready to receive children with special needs. Also, $16 \%$ of them are feeling confident in their capacity of dealing with students in an inclusive classroom.

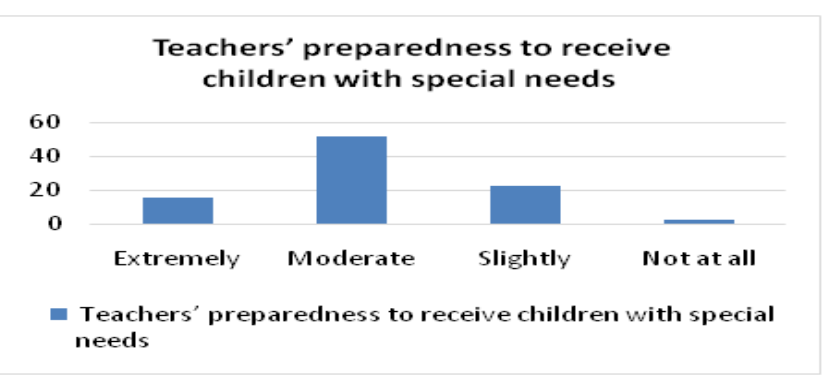

Fig. 3. Teachers preparedness to receive children with special needs.

The fundamental theory which inclusive policies are based on is related to the training of teachers in order to feel ready and sufficiently skilled to work in an inclusive setting. The result of this study is shown in Fig. 4. It shows a real necessity of training teachers regarding inclusive education, and teachers agree that they need training in order to achieve a set of skills to prepare them to work in an inclusive classroom. A significantly percentage of teachers, $73 \%$ of them, agree that a set of skills, a set of teaching methods and of course knowledge is necessary in order to create an adequate environment in the classroom, an environment that respects each other's needs and diversity. A relatively low percentage of teachers, approximately $19 \%$ of them, do not consider it necessary to hold a specific set of skills.

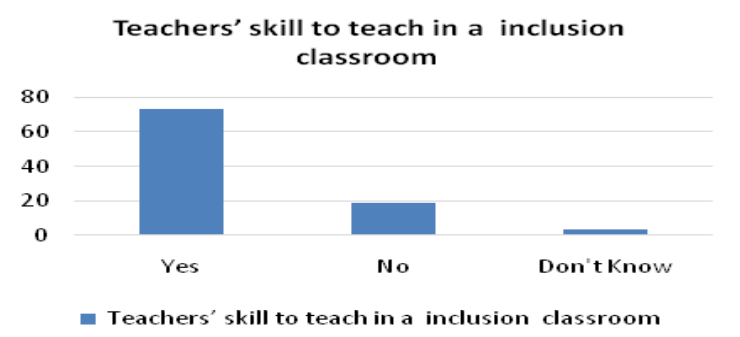

Fig. 4. Teachers skill to teach in an inclusive classroom.

The last question was designed to evaluate to what extend teachers are ready to use a specific teaching strategy in order to adapt their lesson to the needs of children with special needs. So, a percentage of $33 \%$ of teachers fell slightly ready, $12 \%$ extremely ready and $39 \%$ moderately ready to use a specific instructional strategies and methodologies that will meet the requirements of an inclusive classroom as shown in Fig. 5.

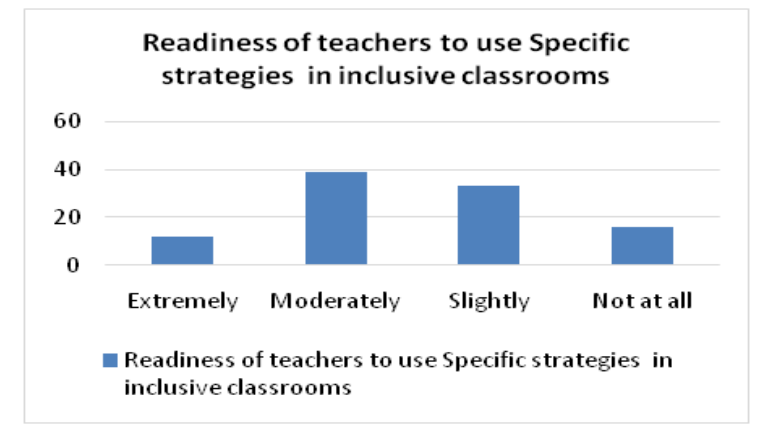

Fig. 5. Readiness of teachers to use specific strategies in inclusive classrooms.

\section{RESUlTS AND DISCUSSIONS}

For critical reviewing the curriculum of Inclusive Education in B.Ed. 2 year Programme, different components i.e. title of the paper and whether its compulsory or elective, year/semester in which the subject is taught, marks allotted to the subject and practical/activities related to the subject were studied which is been given in Table I.

\section{A. Title of the Paper}

After reviewing the curriculum of different Universities of India related to Inclusive Schools, it has been analyzed that the title of the paper/course is "Inclusive school/Creating an Inclusive school/Inclusive Education" as a compulsory subject. However, it has been found that in Lucknow and Banaras Hindu University, this is an optional/elective paper not compulsory.

\section{B. Marks Allotted (Internal and External)}

It has been found that in Panjab University, Punjabi University, Kurukshetra University, Delhi University, Gujarat University and Andhra Pradesh University total marks allotted to inclusive school paper is 50 with internals as well as external (theory). However, in Banaras Hindu University (UP), Dr. Harisingh Gour University Sagar (Madhya Pradesh), University of Jammu, MDU Rohtak, Mumbai University, University of Lucknow and Babasaheb Bhimrao Ambedkar Bihar University Muzaffarpur (Bihar) it comprised of 100 marks with internal and external (theory) whereas in West Bengal University it is 75 marks. 
On the basis of above, it can be said that in some universities Inclusive School is a half mark paper i.e. 50 marks and in some it's full marks i.e. 100 marks with external (theory) and Internal.

\section{Year/Semester in Which the Course Is Studied}

It has been found that in all the universities except University of Jammu and Lucknow, the Inclusive Education paper has been taught in IV semester/II year. On the basis of the above, it can be said that Inclusive Education as a Subject has been taught after School Internship. The pre-service teachers get little opportunity to apply their skills in Inclusive classrooms.

\section{Practical Work/Activities}

Regarding practical work/ Activities, it has been found that practical work has been included in the curriculum of Inclusive Education in all the Universities except Babasaheb Bhimrao Ambedkar Bihar University, Muzaffarpur (Bihar) and Banaras Hindu University, Varanasi (Uttar Pradesh).

The practical work includes preparing a case study on any one/two categories of children with special needs. Preparing report on visit to school practicing inclusion. Preparation of individualized learning materials to meet the needs of a child with any of the disabilities in regular classroom.

The analysis and review of 2-Year B.Ed. curriculum with respect to Inclusive School as a subject reveal some significant insights concerning the direction, scope and quality of the curriculum which has been undertaken in various universities in India. These are listed below:

- Inclusive education in some universities is not compulsory subject. However, it should be a compulsory subject for all teacher candidates and an integral part of teacher training curricula.

- No marks have been allotted to the practical work done by the students both in Internal as well as External exam in most Universities. Teacher education programmes need to consider practical placements in schools and classrooms where inclusion has been embraced as a philosophy and in practice and where there is enough appropriate support to ensure a successful experience for pre-service teachers.

- Pre-service teachers often have limited exposure to and practice with children with special needs. As per the curriculum, the candidates are required to go through a school internship for an average 16 weeks, 2 weeks in 2 sem. / I year and 14 weeks in 3 sem. /II year. Opportunities and direct contact with students with special needs are missing as the subject Inclusive school/Education has been introduced to the students in 4 Semester in most of the universities. So, the question is: Understanding the inclusive Schools/classrooms, should be after or before the Internship programme?

The emphasis of the B.Ed. curriculum is more on theory of Inclusive Education with half credit paper, thus making the teaching incomplete and inadequate. Moreover, to a great extent, the curriculum does not integrate theory with skill-building, through practicum. There is a need to strengthen and modify the existing B.Ed. curriculum of inclusive education focusing on practical part.

\section{CONCLUSION}

Good inclusive teaching does not follow a one-size-fits-all approach but acknowledges that students have different learning needs. Inclusive education largely depends on effective, responsive teachers who can implement differentiated teaching, learning and assessment, with a particular focus on ensuring that students with disabilities and/or learning difficulties participate and progress. A significant challenge, and opportunity, for teachers in the $21 \mathrm{st}$ century is to work within a context of evolving societal change and fast-developing technologies. Teachers now need to deliver teaching and learning that equips students to live, learn and continue to learn in future schools, society and workplaces that, due to the pace of change, were almost unimaginable even as little as 10 years ago. To support learning in this context, teacher professional learning and collaboration both are essential. Leonardo (2010) notes, teachers have a unique opportunity to act as change agents and to transform education. This is because teachers not only implement and innovate instructional approaches, but also provide access to opportunities to learn, to recognise and value difference [16]. Teachers influence students' thinking about issues of global importance that affect their present and shape their future lives.

Education for All in India can only be achieved by including all the excluded, not only those with disabilities, but also child workers, children from certain castes and tribes there is a need for:

- More teachers to be involved in decision making processes within schools.

- Teacher training courses to respond to increased diversity in mainstream classrooms.

Providing access to education is only the first stage in overcoming exclusion from education. There needs to be a shift in perspectives and values so that diversity is appreciated and even celebrated, and teachers are given skills to overcome the cycle of failure and frustration which inevitably results from the present limited teaching practice, insufficient to acquire right set of skills.

\section{ACKNOWLEDGMENT}

The authors appreciate all those who participated in the study and helped to facilitate the research process.

\section{REFERENCES}

[1] UNESCO, The Salamanca Statement and Framework for Action on Special Needs Education, Paris: UNESCO, 1994.

[2] M. T. Ainscow et al., Improving Schools, Developing Inclusion, London: Routledge, 2006

[3] M. Rouse and L. Florian, Inclusive Practice Project: Final Report, 2012.

[4] S. Schaeffer, "Realizing inclusive education through applying a rights-based approach to education," presented at UNESCO International Conference on Education 'Inclusive Education: The Way of the Future' 48th Session, Geneva November 25-28, 2008.

[5] I. Lewis and S. Sagree, "Teachers for all: Inclusive teaching for children with disabilities," International Disabilitiy and Development Consortium Report, Hollingsworth, Cheshire: Enabling Education Network. 2013.

[6] UNESCO, "Inclusive education: The way of the future," Final Report of the International Conference of Education (48th Session), Paris: UNESCO, 2009. 
[7] A. Shaddock et al., "Project to improve the learning outcomes of students with disabilities in the early, middle and post compulsory years of schooling," Canberra, ACT: Australian Government Department of Education, Employment and Workplace Relations, 2007.

[8] L. Florian and M. Rouse, "The inclusive practice project in Scotland: Teacher education for inclusive education," Teaching and Teacher Education, vol. 25, no. 4, pp. 594-601, 2009.

[9] C. M. Cardona, "Teacher education students' beliefs of inclusion and perceived competence to teach students with disabilities in Spain," Journal of the International Association of Special Education, vol. 10, no. 1, pp. 33-41, 2009.

[10] OECD, Investing in Competencies for All, Communiqué of the Education Committee at Ministerial Level, Paris, 2001.

[11] L. Florian, "Teacher education for inclusion," Future Directions for Inclusive Teacher Education, pp. 212-220, Oxon, UK: Routledge, 2012.

[12] M. T. Ahsan et al., "Predicting pre-service teachers' preparedness for inclusive education: Bangladeshi pre-service teachers' attitudes and perceived teaching-efficacy for inclusive education," Cambridge Journal of Education, vol. 43, no. 4, pp. 517-535, 2013.

[13] S. Kumar and G. Rana, "Preparing pre-service teachers for inclusive education," Journal of Educational Review, vol. 7, no. 3, pp. 519-522, 2014.

[14] NCTE, "National curriculum framework for teacher education," Towards Preparing Professional and Humane Teacher, New Delhi, 2009.

[15] Report of the High-Powered Commission on Teacher Education Constituted by the Hon'ble Supreme Court of India, Ministry of Human Resource Development, 2012, vol. 1.

[16] Z. Leonardo, "Affirming ambivalence: Introduction to cultural politics and education," Handbook of Cultural Politics and Education, pp. 1-45, Rotterdam: Sense Publishers, 2010.

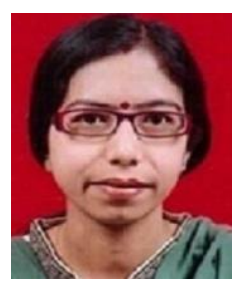

Pushpa Kumari is doctoral student in School of Educational studies, Dr. Harisingh Gour Vishwavidyalya, Sagar, Madhya Pradesh, India PIN470003. She has done her masters in physics, sociology and education. As a researcher she had attended many national as well as international conferences in India and Abroad. As a member of ESREA recently she presented papers at international conferences at Rennes University, France and Leeds Beckett University United Kingdom. Presently she is working on inclusive education of children with special needs in India. Many research articles have been published by her in national as well as international Journals. She is a visiting faculty in Delhi University in Department of Education.

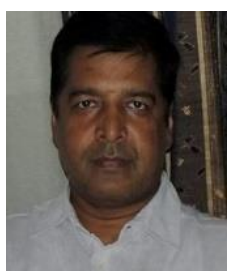

Rajiv Nayan is assistant professor, the Department of Commerce, Ramanujan College, University of Delhi, India PIN-110014. Dr Rajiv Nayan M.Com, MBA, $\mathrm{PhD}$ is currently working as an assistant professor in the Department Of Commerce at Ramanujan College, University of Delhi. Dr. Nayan has eight years of teaching experience and has supervised more than 10 MBA dissertations. He has participated in number of
National and International seminars and conference. Dr. Nayan has two books and more than eight research papers published in leading National and International Journals and periodicals of the country and two Minor research projects and one major research project on his credit. His area of specialization is International Business, Business Environment and Government Policy and Social Issue. At present, besides teaching, he is actively engaged in guiding scholars in the area of various commerce papers and educational paper including those focusing on inclusive education addressing diverse population of learners in India. He is also member of various College committees in Ramanujan College, University of Delhi.

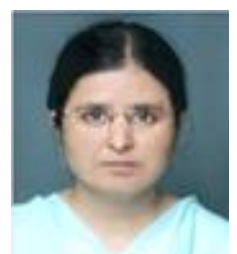

Geetanjali Baswani is doctoral student in School of Educational studies, Dr. Harisingh Gour Vishwavidyalya, Sagar, Madhya Pradesh, India PIN470003. She has done her masters in chemistry, library science and education. She has a teaching experience of $10 \mathrm{yrs}$ in College of Education as assistant professor. She had participated in many national as well as international seminars and conferences in India and abroad. She attended Winter School in Germany in Feb 2017 and Verona, Italy in Dec 2017. Recently, she participated in international conferences of ESREA, at Rennes University, France and Leeds Beckett University, United Kingdom.

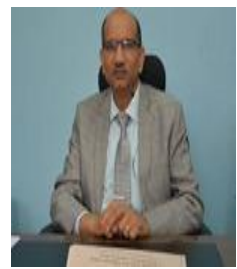

S. P. Aggarwal is Principal, Ramanujan College, University of Delhi is a dynamic visionary, exemplary leader, outstanding administrator, passionate researcher and a motivational teacher and mentor. Dr. Aggarwal obtained his professional qualifications of M.A. (IMS) and M.B.A. (Finance) from the prestigious Universities of Texas and Houston, both based in U.S.A. An alumnus of Shri Ram College of Commerce and Department of Commerce, Delhi School of Economics of University of Delhi, he obtained his Doctorate from Sambalpur University, Orissa in Management. Early in his life phase as a young researcher, he received fellowships from Government of India for research and studying abroad. In an academic career spanning more than 3 decades, he has taught as visiting and full time faculty in several Indian and foreign Universities. He was invited by the Association of International Accountants (AIA), London as an Academic Member to attend the meetings wherein he presented a comprehensive plan in the area of International Accounting.

As an administrator and leader, he has brought about a paradigm change in the functioning of Ramanujan [erstwhile Deshbandhu (Evening)] College by being at the forefront of establishing structures, systems, and processes, implementing creative and innovative ideas and leading by example. As a result of his guidance and concreted efforts, the college recently got an "A" grade accreditation from NAAC. Following the accreditation, he has also visited several Institutions as a NAAC Peer Team Member or Member Coordinator.

He has been honoured with the "PPS Millennium National Teachers Award" by the Institute for Environment, Yoga \& Social Security and the "Distinguished Alumni Award" by the Shri Ram College of Commerce, University of Delhi. 